\title{
Pengaruh PPN, PKB Tarif Progresif, dan Pendapatan WP pada Daya Beli Konsumen Kendaraan Bermotor
}

\author{
I G. A. Bella Lestari ${ }^{1}$ \\ Fakultas Ekonomi dan Bisnis \\ Universitas Udayana, Indonesia
}

\author{
Made Yenni Latrini ${ }^{2}$ \\ Fakultas Ekonomi dan Bisnis \\ Universitas Udayana, Indonesia
}

Surel : gustiayubella@yahoo.co.id

ABSTRAK

Daya beli konsumen dapat dipengaruhi oleh beberapa faktor terutama saat pembelian kendaraan bermotor adalah adanya PPN dan PKB Tarif Progresif yang dikenakan saat membeli kendaraan bermotor. Penelitian ini bertujuan untuk meninjau pengenaan PPN, PKB Tarif Progresif, dan pendapatan WP pada daya beli konsumen terhadap pembelian kendaraan bermotor. Penelitian bertempat di kantor SAMSAT bersama kota Denpasar. Penelitian ini berjumlah 100 responden. Regresi linear berganda merupakan teknik analisis yang digunakan dalam penelitian ini. Mengacu pada hasil analisis ditemukan jika pengaruh pajak pertambahan nilai dan pendapatan WP memberi pengaruh signifikan pada daya beli. Sedangkan PKB tarif progresif tidak memberi pengaruh pada daya beli konsumen. Penelitian ini mengkonfirmasi teori asas daya beli dan teori prestise.

Kata Kunci: $\quad$ PPN; PKB Tarif Progresif; Pendapatan WP; Daya Beli Konsumen.

\section{The Effect of VAT, Progressive PKB Tariffs, and Taxpayer Revenues on the Purchasing Power of Motor Vehicle Consumers}

\begin{abstract}
Consumer purchasing power can be influenced by several factors, especially when purchasing motor vehicles is the existence of VAT and Progressive $P K B$ rates that are imposed when buying a motorized vehicle. This study aims to review the imposition of VAT, PKB Progressive Rates, and WP income on consumer purchasing power for the purchase of motor vehicles. The research took place in the SAMSAT office with the city of Denpasar. This study amounted to 100 respondents. Multiple linear regression is an analysis technique used in this study. Referring to the results of the analysis found that the effect of value added tax and income WP has a significant influence on purchasing power. Whereas progressive tariff PKB does not influence consumer purchasing power. This research confirms the theory of the principle of purchasing power and the theory of prestige.
\end{abstract}

Keywords: VAT; Motor Vehicle Tax with Progressive Rates; Taxpayer Income; Purchasing Power.

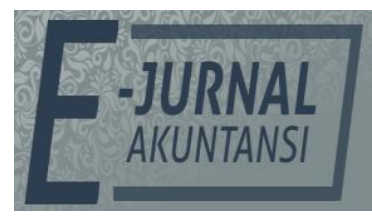

e-ISSN 2302-8556

Vol. 30 No. 8

Denpasar, Agustus 2020

Hal. 2127-2137

DOI:

10.24843/EJA.2020.v30.i08.p18

PENGUTIPAN:

Lestari, I G. A. B. \& Latrini,

M. Y. (2020). Pengaruh PPN,

PKB Tarif Progresif, dan

Pendapatan WP pada Daya

Beli Konsumen Kendaraan Bermotor. E-Jurnal Akuntansi, 30(8), 2127-2137

RIWAYAT ARTIKEL: Artikel Masuk: 27 Januari 2020 Artikel Diterima: 16 Juli 2020

Artikel dapat diakses : https://ojs.unud.ac.id/index.php/Akuntansi/index 


\section{PENDAHULUAN}

Ekonomi yang maju dapat dilihat pada berbagai sektor, khususnya dalam sektor penerimaan negaranya. Indonesia sendiri terdapat berbagai sektor penerimaan negara salah satunya adalah pajak. Pajak sendiri merupakan iuran yang diperoleh dari uang rakyat terhadap kas Negara yang mengacu pada perundangundangan serta dapat dipaksa dengan catatan tidak memperoleh jasa timbale balik, sehingga dapat diperlihatkan dan dipakai dalam membayar pengeluaran secara umum (Soemitro, 2016:1). Sektor pajak adalah prioritas utama di Indonesia (Pitaloka et al, 2018). Untuk meningkatkan pendapatan oleh Negara maka pemerintah pada hal ini adalah tugas Direktorat pada jabatan Jenderal Pajak harus membuat lebih pendapatan terhadap pajak (Raharjo \& Bieattant, 2018). PPN adalah pajak yang memberi pengaruh pada pendapatan yang ada dalam suatu negara. PPN merupakan pajak yang menggantikan pajak penjualan (Komal, 2013). Salah satu elemen terpenting dalam penerimaan suatu negara adalah PPN (Bikas, 2013). PPN adalah salah satu sumber penting pendapatan pemerintah (Tareke et al 2013). Undang-Undang menjelaskan tentang pajak yang digunakan sebagai pertambahan nilai atau disingkat menjadi (PPN) yaitu pajak yang menjadi konsumsi sebuah barang serta jasa pada daerah yang berlokasi di pabean yang digunakan dengan cara bertingkatdi tiap jalur yang berproduksi serta terdistribusi. PPN merupakan sebuah pajak yang digunakan pada penambahan nilai atau disebut Value added yang muncul karena dapat dipakai sebagai faktor-faktor produksi pada tiap jalur perusahaan guna persiapan, penghasil, penyaluran serta perdagangan barang dan sebagi pemberi pelayanan berupa jasa pada para konsumen (Rahayu, 2010:36). Pengenaan PPN bertujuan untuk mengenakan pajak pada tingkat kemampuan WP dalam hal berkonsumsi. Pengenaan PPN telah menyebar sangat baik di beberapa negara (Alavuotunki et al 2019). PPN dianggap lebih baik untuk pertumbuhan ekonomi dibandingkan dengan pajak tidak langsung lainnya (Miki, 2011).

Selain PPN, pajak yang dapat mendominasi sebuah pendapatan yang berada di suatu Negara yaitu PKB, seperti kendaraan yang roda duaserta roda empat. PKB diharapkan dapat menjadi alat yang baik untuk kebijakan negara (David, 2012). Total kendaraan di kota Denpasar baik tahun 2014 hingga 2018 mencapai 6.190.923 (Statistik, 2019). Jumlah kendaraan bermotor pada tahun 2014 hingga 2018 beserta rincian jenis kendaraannya akan ditampilkan dalam Tabel 1.

Tabel 1. Jumlah Unit Kendaraan Roda Dua dan Roda Empat di Kota Denpasar Periode 2014-2018

\begin{tabular}{lccc}
\hline Tahun & $\begin{array}{l}\text { Jumlah Kendaraan } \\
\text { Bermotor Roda Dua } \\
\text { (Unit) }\end{array}$ & $\begin{array}{c}\text { Jumlah } \\
\text { Kendaraan } \\
\text { Bermotor Roda } \\
\text { Empat (unit) }\end{array}$ & Jumlah (Unit) \\
\hline 2014 & 915.888 & 154.567 & 1.070 .455 \\
2015 & 977.774 & 162.590 & 1.140 .364 \\
2016 & 1.026 .430 & 168.860 & 1.195 .290 \\
2017 & 1.068 .191 & 175.932 & 1.244 .123 \\
2018 & 1.118 .525 & 185.350 & 1.303 .875 \\
\hline
\end{tabular}

Sumber: Badan Pusat Statistik, 2019 
Mengacu pada Tabel 1, memperlihatkan bahwa jika kepemilikan kendaraan bermotor roda dua melebihi jumlah kendaraan roda empat. Hal tersebut dikarenakan harga pada kendaraan bermotor roda dua sangan banyak peminatnya serta lebih mudah untuk dijangkau oleh masyarakat luas. Ditambah lagi dengan banyaknya penduduk yang mengenakan kendaraannya pribadi sebagai pembanding transformasi pada kendaraan umum. Harga kendaraan bermotor yang mudah dijangkau oleh masyarakat di Kota Denpasar, menyebabkan masyarakat sangat gampang membeli sebuah kendaraan bermotor baik beroda dua maupun yang beroda empat. Hal ini dapat menyebabkan peningkatan pada jumlah kendaraan yang berdampak terhadap macetnya arus lalu lintas yang berada di Kota Denpasar. Kemacetan tersebut menyebabkan banyak kerugian baik secara fisik maupun materi.

Untuk mengatasi masalah tersebut maka, pemerintah Provinsi Bali mengeluarkan surat edaran No 119/1718 Dispendan. Pengenaan pajak pada kepemilikan motor sebenarnya tidak jauh beda pengenaan pajak progresifnya, $2 \%$ untuk pemilik pertama, 2.5\% untuk pemilik kedua, 3\% untuk pemilik ketiga, seterusnya. Dengan adanya penerapan PKB tarif pajak progresif ini di usahakan dapat meneka angka sebuah kemaceten yang terjdi di kota Denpasar. Namun pemerintah harus berhati-hati dalam menerapkan PKB tarif progresif ini (Fajariani, 2013). PPN dan PKB tarif progresif ini pada nantinya akan memberi pengaruh pada harga jual sebuah kendaraan dan hal tersebutlah yang menyebabkan konsumen berpikir dua kali akibat dikenakannya biaya tarif PPN serta PKB pada tarif progresif ini (Devi \& Supadmi, 2017). Namun pada kenyataannya masih banyak WP belum memenuhi kewajiban mereka dalam membayar Pajak Kendaraan Bermotor (Lulus \& Surjanti, 2018).

Hal yang mempengaruhi daya beli selain harga jual adalah jumlah pendapatan dari konsumen itu sendiri. Daya beli merupakan kemampuan dimana seorang konsumen mampu untuk memebeli sebuah barang serta jasa yang sesuai dengan kmampuan serta kebutuhannya (Supawi, 2016:7). Bila pendapatan konsumen meningkat maka keinginan konsumen dalam pemebelian barang serta jasa lebih tinggi dibandingkan sebelum pendapatan mereka meningkat (Utami, 2015). Aspek sosial dan psikologis wajib pajak dipengaruhi oleh tingkat pendapatan mereka (Eragbhe \& Aronmwan, 2015). Dengan adanya pendapatan WP yang tinggi maka hal tersebut menyebabkan WP tidak akan berfikir dua kali untuk membeli kendaraan. Hal tersebut dikarenakan harga dari pada penjualan serta beban dari pajak yang masih bisa dijangkau oleh WP untuk membeli kendaraan bermotor. (Chaerannisah, 2014). Penduduk akan memikirkan barang yang ingin dibelinya dan memperhitungkan kenaikan harga dari kendaraan karena dikenakan PPN, naiknya pembayaran PKB dengan memakai tarif pada pajak progresif, serta pendapatan WP mereka.

Menurut Fadilah, (2012) daya beli adalah kemampuan yang dimiliki oleh seseorang dalam pemakaian sebuah produk. Selain itu daya beli juga dipengaruhi oleh beberapa faktor, yaitu usia, pendapatan, pendidikan, jenis kelamin, dan status pernikahan (Lee, 2005).

Jika kualitas kendaraan bermotor WP tersebut tinggi maka harga kendaraan dan PPN yang dikenakannya pun tinggi. Tentu saja dengan harga kendaraan yang tinggi tersebut dapat menaikkan prestise dari pemilik 
kendaraan tersebut (Irwanto, 2015). Hasil penelitian dari Ayuningtyas, (2010), Alizadeh \& Motallabi, (2016), Ahmed, (2015), Fadilah, (2012), Abdurrahman Raja, (2014), dan Devi \& Supadmi, (2017) mengenai PPN dalam kaitannya kepada daya beli dari seorang konsumen pada suatu kendaraan hal tersebut memberi gambaran jika PPN memberi pengaruh yang positif kepada daya beli dari seorang konsumen, yang disebabkan pengenaan PPN langsung dikenakan saat pembelian kendaraan bermotor. Mengacu Pada penelitian terdahulu didapatkan rumusan hipotesis seperti berikut:

$\mathrm{H}_{1}$ : PPN memberi pengaruh positif kepada daya beli konsumen sebuah kendaraan bermotor.

Makin banyaknya kendaran yang sudah dimiliki oleh masyarakat, maka pengenaan pajak progresif nya pun semakin tinggi. Teori asas daya beli berkaitan dengan pengenaan pada tarif progresif dari PKB, dimana PKB tarif dari pajak progresif menyebabkan konsumen harus membayar tarif dari pajak progresif pada pemilik kendaran kedua serta seterusnya. Sehingga minat konsumen untuk membeli kendaraan tersebut akan menurun. Pengenaan PKB dapat meningkatkan pendapatan suatu provinsi ditambah lagi dengan pengenaan tarif progresif. Penelitian Ratnasari \& Setiawan, (2016) dan Devi \& Supadmi, (2017) mengenai PKB terhadap daya pembelian konsumen mendapatkan hasil jika PKB memberi pengaruh yang negatif kepada daya beli dari seorang konsumen khusus untuk kendaraan bermotor. Hal tersebut dikarenakan peningkatan pajak membuat daya untuk membeli kendaraan bermotor akan menurun. Dari penelitian terdahulu didapatkan rumusan hipotesis seperti berikut.

$\mathrm{H}_{2}$ : PKB dengan tarif pajak progresif memberi pengaruh yang negatif kepada daya beli dari seorang konsumen khusus untuk kendaraan bermotor.

Kepemilikan kendaraan bermotor yang tergolong mewah tentunya akan meningkatkan prestise seseorang. Hal-hal yang berkesan modern dan membawa prestise lebih diminati oleh banyak orang saat ini (Wibowo \& Riyadi, 2017). Kendaraan yang mewah akan terkena pajak yang cukup tinggi. Pendapatan setiap WP berbeda-beda. Hal tersebut berkaitan dengan prestise yang di miliki oleh tiap wajib pajak. Pendapatan wajib sebuah pajak yang meningkat akan meningkatkan pula prestise nya. Hal tersebut yang mendorong wajib pajak untuk membeli kendaraan yang lebih mewah, agar lebih merasa dihormati atau disegani di lingkungannya. Jika pendapatan WP meningkat maka daya beli pun juga akan meningkat, tanpa harus memikirkan besarnya pajak yang akan dibebankan pada nantinya (Hetriana, 2015).

Penelitian oleh Ridwan, (2012) memberi gambaran jika pendapatan memberi pengaruh positif terhadap daya beli. Hal tersebut di dukung oleh Chaerannisah, (2014), Hetriana, (2015), dan Adiputri \& Jati, (2018) yang menyebutkan pendapatan memberi pengaruh yang positif kepada daya beli. Dari penelitian sebelumnya didapatkan rumusan hipotesis seperti berikut.

$\mathrm{H}_{3}$ : Pendapatan WP memberi pengaruh positif kepada daya beli dari seorang konsumen khusus untuk kendaraan bermotor. 


\section{METODE PENELITIAN}

Penelitian ini adalah penelitian yang berjenis kuantitattif dengan bentuk asosiatif. Penelitian ini dilakukan di Kantor SAMSAT Bersama Denpasar, sebab di Kantor SAMSAT masyarakat umumnya mengurus masalah kepemilikan dan pembelian kendaraan bermotor. Obyek penelitian yang dipakai pada penelitian ini yaitu daya beli dari seorang konsumen kepada kendaraan bermotor yang setelah dikenakan biaya PPN serta PKB pada tarif pajak progresif. Populasi dalam penelitian ini berjumlah 1.303.875 responden dan sample yang didaptkan adalah sebesar 100 responden diambil dari rumus slovin. Variabel bebas pada penelitian ini yaitu PPN $\left(X_{1}\right)$, PKB pada Tarif pajak yang progresif $\left(X_{2}\right)$, dan Pendapatan WP $\left(X_{3}\right)$. Sedangkan Variabel terikatnya adalah Daya Beli dari seorang Konsumen khusus untuk Kendaraan Bermotor (Y). Data kuantitattif merupakan jenis data yang dipakai untuk mengetahui data tentang kepemilikan kendaraan bermotor yang berada di kawasan Denpasar. Data kualitattif dari penelitian ini adalah jawaban responden kepada kuesioner yang telah dibagikan terkait dengan PPN, PKB pada tarif pajak progresif, Pendapatan WP, dan Daya Beli. Sumber data yang dipakai yaitu data primer serta data skunder. Data primer dalam penelitian ini yaitu tanggapan dari responden terkait kuesioner yang telah diberikan. Sedangkan data skunder dalam penelitian ini adalah data tentang kepemilkan kendaran bermotor yang di dapat dari Kantor SAMSAT yang berada. Metode untuk penentuan sampel yang dipakai adalah Nonprobability Sampling dengan teknik Purposive Sampling. (Sugiyono, 2019:144). Teknik analisis data yang digunakan dalam penelitian ini adalah analisis linear berganda, dimana teknik ini menguji hubungan secara linear atara dua atau lebih variabel independen dengan variabel dependen. Model persamaan untuk teknik ini yaitu sebagai berikut.

$Y=\alpha+\beta 1 X 1+\beta 2 X 2+\beta 3 X 3+\varepsilon$

Teknik analisis data dalam penelitian ini terdiri dari uji statistik deskriptif, uji kualitas data dimana uji kualitas data itu terdiri dari uji validitas dan uji reliabilitas. Selain uji statisik deskriptif, uji asumsi klasuk juga terdapat dalam teknik analisis penelitian ini dimana uji asumsi klasik terdiri dari uji normalitas, uji multikolinieritas, dan uji heteroskedatisitas. Sedangkan untuk uji regresi linear berganda terdiri dari uji koefisien determinasi, uji kelayakan model, dan uji hipotesis.

\section{HASIL DAN PEMBAHASAN}

Penelitian ini bertujuan untukmengetahui seberapa besar pengaruh pajak dari pertambahan nilainya, pajak sebuah kendaraan bermotor yang sudah dikenakan tarik pajak progresif, serta pendapatan yang diperoleh untuk wajib pajak kepada daya beli dari konsumen yang ada di kota Denpasar.

Tabel 2. Jumlah Penyebaran dan Pengembalian Kuesioner

\begin{tabular}{llll}
\hline No & Tempat Penyebaran Kuesioner & $\begin{array}{l}\text { Jumlah Kuesioner } \\
\text { Tersebar }\end{array}$ & $\begin{array}{l}\text { Jumlah Kuesioner } \\
\text { Kembali }\end{array}$ \\
\hline 1 & $\begin{array}{l}\text { Kantor SAMSAT Bersama Kota } \\
\text { Denpasar }\end{array}$ & 100 & 100 \\
Total & & 100 & 100 \\
\hline
\end{tabular}

Sumber: Data Penelitian, 2019 
Mengacu pada Tabel 2, mampu dilihat jika total kuesioner yang telah tersebar berjumlah 100 eksemplar serta keseluruhan kuesioner tersebut dapat dipakai.

Tabel 3. Hasil Uji Statistik Deskriptif

\begin{tabular}{lccccc}
\hline & $\mathrm{N}$ & Min. & Max. & Mean. & Std.Deviasi \\
\hline Pajak. Pertambahan. Nilai (X1) & 100 & 17,00 & 32,00 & 23,74 & 3,01 \\
$\begin{array}{l}\text { Pajak. Kendaraan. Bermotor. dengan.100 } \\
\text { Tarif. Progresif (X2) }\end{array}$ & 10,00 & 20,00 & 13,59 & 2,09 \\
$\begin{array}{l}\text { Pendapatan. Wajib. Pajak (X3) } \\
\text { Daya. Beli. Konsumen (Y) }\end{array}$ & 100 & 14,00 & 28,00 & 21,26 & 2,82 \\
\hline
\end{tabular}

Sumber: Data Penelitian, 2019

Mengau pada tabel 3 memberi gambaran bahwa setiap variabel memperlihatkan perbedaan di tiap nilai yang diteliti dengan nilairata-ratanya atau std deviasi.

Tabel 4. Hasil Uji Validitas

\begin{tabular}{lll}
\hline Variabel & Instrumen & PearsonCorrelation \\
\hline PajakPertambahanNilai & X1,1 & 0,560 \\
& X1,2 & 0,730 \\
& X1,4 & 0,753 \\
X1,5 & 0,719 \\
X1,6 & 0,679 \\
X1,7 & 0,517 \\
X1,8 & 0,688 \\
Pajak Kendaraan Bermotor dengan TarifX2,1 & 0,699 \\
Progresif & X2,2 & 0,579 \\
& X2.3 & \\
& X2,4 & 0,838 \\
Pendapatan Wajib Pajak & X2,5 & 0,738 \\
& X3,1 & 0,707 \\
& X3,2 & 0,592 \\
X3,4 & 0,600 \\
X3,5 & 0,560 \\
Xaya Beli Konsumen & X3,7 & 0,747 \\
& Y1 & 0,668 \\
& Y2 & 0,579 \\
& Y3 & 0,718 \\
& Y5 & 0,784 \\
& & 0,872 \\
& & 0,899 \\
& 0,758 \\
& 0,697 \\
& & 0,826 \\
\hline
\end{tabular}

Sumber: Data Penelitian, 2019

Tabel 4, Memberi gambaran jika variabel PPN, PKB pada tarif progresif, pendapatan dari WP, serta daya beli seorang konsumen punya nilai $\mathrm{r}$ pearson correlation melebihi dari 0,30. Jika sebuah nilai tersebut melebihi 0,30 maka pernyataan yang ada didalam kuesioner itu dinyatakan valid. Dapat dilihat dari perolehan pearson correlation yang menunjukkan bahwa nilainya semua berada melebihi 0,30 . 
Tabel 5. Hasil Uji Reliabilitas

\begin{tabular}{ll}
\hline Variabel & Cronbach's_Alpha \\
\hline PajakPertambahan. Nilai (X1) & 0,804 \\
Pajak. Kendaraan Bermotor denganTarif & 0,707 \\
Progresif (X2) & \\
PendapatanWajib. Pajak (X3) & 0,790 \\
Daya. BeliKonsumen (Y) & 0,864
\end{tabular}

Sumber: Data Penelitian, 2019

Mengacu pada Tabel 5, maka didapatkan kesimpulan jika keempat instrument penelitian tersebut telah mempunyai koefisien dari pada Cronbach's alpha melebihi 0,70. Sehingga pernyataan yang ada pada kuessioner itu dapat dinyatakan relliabel.

\section{Tabel 6. Hasil Uji Normalitas}

\begin{tabular}{ll}
\hline Kolmogorov-Smirnov & Unstandardized_Residual \\
\hline $\mathrm{N}$ & 100 \\
Asymp.Sig(2 -tailed $)$ & 0,053 \\
\hline
\end{tabular}

Sumber: Data Penelitian, 2019

Mengacu pada Tabel 6, maka dapatdisimpulkan jika data berdistribusi normal yang diperlihatkan dengan nilai sig senilai 0,053 yang melebihi 0,05 . Jadi data pada tabel diatas berdistribusi normal karena lebih dari 0,05.

Tabel 7. Hasil Uji Multikolinieritas

\begin{tabular}{|c|c|c|}
\hline Variabel & Tolerance & VIF \\
\hline $\begin{array}{l}\text { PajakPertambahan Nilai } \\
\text { (X1) }\end{array}$ & 0,873 & 1,145 \\
\hline $\begin{array}{l}\text { Pajak Kendaraan Bermotor } \\
\text { Dengan Tarif progresif }(X 2)\end{array}$ & 0,771 & 1,297 \\
\hline $\begin{array}{l}\text { Pendapatan Wajib Pajak } \\
\text { (X3) }\end{array}$ & 0,695 & 1,439 \\
\hline
\end{tabular}

Sumber: Data Penelitian, 2019

Dari Tabel 7, tersebut didapatkan kesimpulan jika tidak terdapat variabel bebas ddalam menghasilkan nilaitolerance yang kurang dari 0,10. Perhitungan VIF pada Tabel 7, memberi gambaran jika tidak ada satupun variabel bebas menghasilkan lebih dari 10 . Hal tersebut memberi gambaran jika tidak adanya gejala yang disebut sebagai multikolinieritas diantara variabel.

\section{Tabel 8. Hasil Uji Heteroskedatisitas}

\begin{tabular}{lc}
\hline Variabel & Signifikansi \\
\hline Pajak Pertambahan Nilai (X1) & 0,331 \\
PajakKendaraa Bermotordengan Tarif Progresif $(X 2) 0,061$ \\
Pendapatan Wajib Pajak (X3) & 0,431
\end{tabular}

Sumber: Data Penelitian, 2019

Dari Tabel 8, didapatkan kesimpulan jika nilai signifikansi pada tiap variabel tersebut melebihi 0,05 . Sehingga hal tersebut memberi gambaran jika tidak terdapat gejala heteroskedatisitas. Hal tersebut mengartikan bahwa tidak ada satupun variabel bebas berpengaruh signifikan terhadap variabel terikat. Maka dari itu model regresi ini dapat dikatakan bebas dari gejala heteroskedatisitas. 
Tabe1 9. Hasil Analisis Regresi Linear Berganda

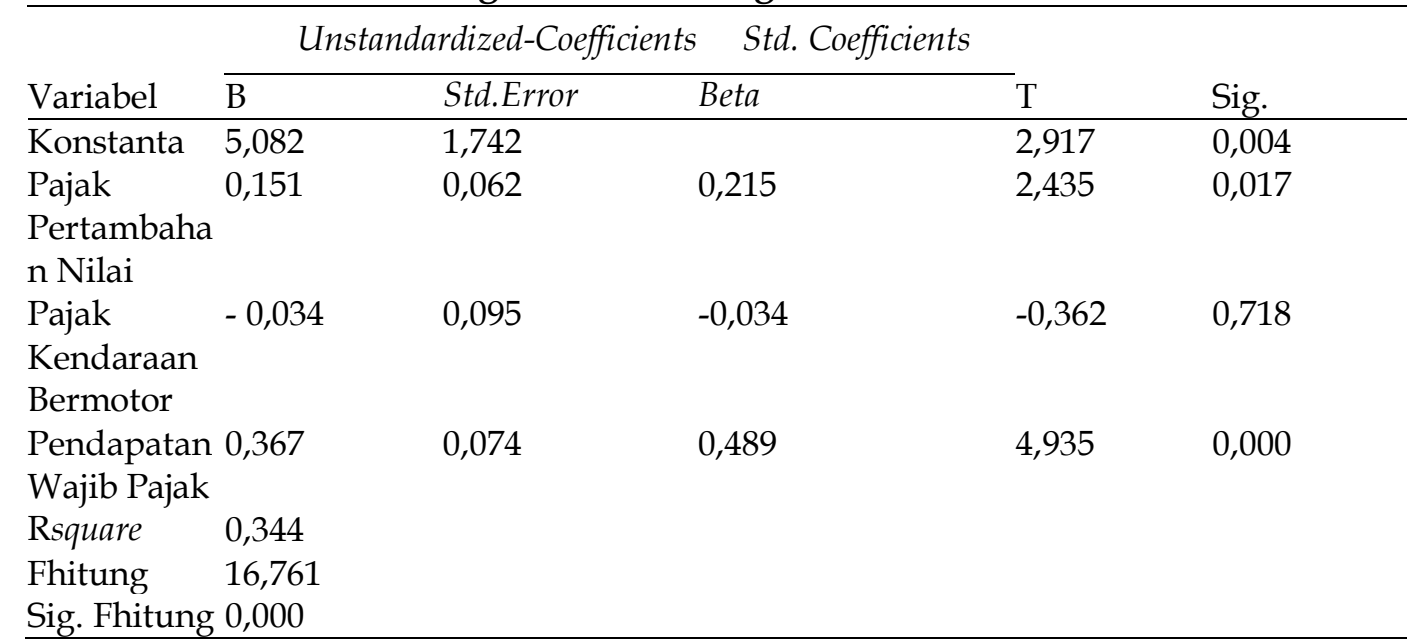

Sumber: Data Penelitian, 2019

Mengacu pada Tabel 9, dapat disusun persamaan regresi seperti berikut.

$$
\mathrm{Y}=5,082+0,151 \mathrm{X} 1-0,034 \mathrm{X} 2+0,367 \mathrm{X} 3+\varepsilon
$$

Dari Tabel 9, didapatkan kesimpulan jika nilai dari Adjusted R-Square senilai 0,344 yang berarti jika 34,40\% variasidaya beli konsumen di penagruhi oleh PPN, PKB Tarif pajak progresif, serta Pendapatan WP. Dan senilai 65,60\% dipengaruhi oleh faktor-faktor lainnya.

Dari Tabel 9, memberi gambaran jika hasil nilai signifikansinya senilai 0,000 kurang dari 0,05. Hal tersebut memberi gambaran jika uji regresi linier berganda layak dipakai.

Hipotesis pertama dalam Tabel 9, Dapat diterima dikarenakan nilai signifkansi yaitu pada uji-t untukvariabel PPN senilai 0,017 kurang dari $\alpha=0,05$ serta nilaikoefisien regresinya senilai 0,151. Maka dari hasil tersebut di dapatkan jika PPN memberi pengaruh yang positif kepada daya beli dari seorang konsumen khusus untuk kendaraan bermotor. Hal tersebut mengartikan jika semakin besar PPN yang dikenakan, maka semakin besar juga PPN dapat memengaruhi daya beli dari seorang konsumen khusus untuk pembelian kendaraan yang bermotor. Penelitian didukung oleh Ayuningtyas, (2010), Fadilah, (2012), Abdurrahman Raja, (2014), dan Devi \& Supadmi, (2017) yang mengatakan jika PPN memberi pengaruh yang positif kepada proses daya beli dari seorang konsumen. Hal tersebut dikarenakan pengenaan PPN dilakukan secara tidak langsung, yaitu saat pembelian kendaraan bermotor. Kepemilikan kendaraan bermotor mengonfirmasi adanya teori prestise, dimana dengan membeli kendaraan bermotor maka konsumen dapat menaikkan prestise dalam dirinya. Konsumen akan tertarik membeli membeli kendaraan bermotor dilihat dari kualitas kendaraan itu sendiri, semakin tinggi kualitasnya maka semakin meningkat harga yang perlu dibayarkan.

Hipotesis kedua pada penelitian ini adalah ditolak hal ini dikarenakan nilai sig pada uji-t dari variabel PKB dengan dikenakan tarif pada pajak progresif senilai 0,718 melebihi $a=0,05$ serta nilai koefisien regresinya senilai $-0,034$. Maka dari hasil tersebut di dapatkan jika PKB dengan tarif pada pajak progresif tidak memberi pengaruh kepada daya beli dari seorang konsumen khusus untuk 
kendaraan bermotor. Hal tersebut mengartikan jika semakin besar pengenaan sebuah PKB yang dikenakan tarif pada pajak progresif maka tidak akan ada pengaruhnya kepada daya beli dari seorang konsumen khusus untuk kendaraan bermotor. Penelitian ini tidak sejalan dengan Ratnasari \& Setiawan, (2016) dan Devi \& Supadmi, (2017) yangmenemukan jika PKB tarifprogresif memberi pengaruh yang negatif serta signfikan kepada dayabeli dari seorang konsumen khusus untuk kendaraan bermotor. Mengacu Pada data tersebut terdapat beberapa hal yang menyebabkan PKBdengan tarifprogresif tidak memberi pengaruh kepada daya beli seorang konsumen kendaraanbermotor. Sesuai dengan hasil pengumpulan kuesioner beberapa responden menyatakan jika besarnya denda pajak tidak memberi pengaruh kepada daya beli dari seorang konsumen khusus untuk kendaraan bermotor. Hal tersebut mengindikasikan jika pengenaan tarif progresif belum mampu menurunkan minat konsumen dalam membeli kendaraan bermotor. Selain besarnya denda pajak tidak dapat memengaruhi daya beli konsumen, hal lainnya yang menyebabkan PKB tidak memengaruhi daya beli seorang konsumen adalah tarif yang tidak terlalu besar sehingga masih bisa dijangkau oleh masyarakat sekitar. Selain itu, hal yang menyebabkan PKB pada tarif progresif tidak dapat memengaruhi daya beli konsumen adalah dikarenakan perindustrian yang sudah bekembang cukup pesat, sehingga kenyamanan serta kecanggihan tetap menjadi primadona bagi sebagian masyarakat. Kondisi ini di dukung oleh pembelian kendaraan yang semakin hari semakin meningkat walaupun sudah diberlakukannya tarif progresif dan juga prestise dari masyarakat terhadap pembelian kendaraan bermotor.

Hipotesis ketiga pada penelitian ini adalah diterima dikarenakan nilai sig. pada uji-t untuk pendapatan WP senilai 0,000 kurang dari $a=0,05$ serta nilai koefisien regresinya senilai 0,367 . Maka dari hasil tersebut di dapatkan jika pendapatan WP memberi pengaruh yang positif kepada daya beli dari seorang konsumen khusus untuk kendaraan bermotor. Hal tersebut mengartikan jika semakin besar pendapatan WP yang dikenakan maka semakin besar pula pengaruhnya kepada daya beli dari seorang konsumen khusus untuk kendaraan bermotor. Penelitian didukung oleh Ridwan, (2012), Chaerannisah, (2014), Hetriana, (2015), dan Adiputri \& Jati, (2018) yang menemukan jika pendapatan wajib pajak memberi pengaruh yang positif serta signifikan kepada daya beli dari seorang konsumen khusus untuk kendaraan bermotor. Hasil penelitian tersebut mengonfirmasi adanya teori asas daya beli pada variabel pendapatan WP, dimana Pendapatan yang diterima dipakai untuk pembayaran pajak. Bayaran dari WP ini akan dipakai kas sebagai pembiayaan pengeluaran secara umum sebagai upaya dalam peningkatan kesejahtraan WP itu sendiri.

\section{SIMPULAN}

PPN memberi pengaruh positif kepada daya beli dari seorang konsumen khusus untuk kendaraan bermotor. PKB dengantarif progresif tidak memberi pengaruh kepada dayabeli dari seorang konsumen khusus untuk kendaraan bermotor. Pendapatan WP memberi pengaruh yang positif kepada daya beli dari seorang konsumen khusus untuk kendaraan bermotor. Pemerintah sebaiknya lebih memperhatikan pengenaan PPN, PKB dengan tarif progresif, serta pendapatan 
WP yang akan memberi pengaruh terhadap daya beli konsumen, sehingga pengenaan pajaknya dapat di realisasikan dengan benar dan tepat sasaran.

\section{REFERENSI}

Abdurrahman Raja. (2014). Analisis serta Pengaruh pada pertumbuhan Pajak dalam Pertambahan sebuah Nilai (PPN) dan Pajak Penjualan atas Barang Mewah (PPNBM) terhadap Daya Beli Konsumen pada Kendaraan Bermotor (Studi Empiris pada Konsumen Kendaraan Bermotor Roda Empat diwilayah Kota Tanjungpinang). E-Jurnal Umrah.

Adiputri, G. S., \& Jati, I. K. (2018). Pengaruh PKB pada Tarif pajak Progresif dan Pendapatan dari WP Kepada Daya Beli dari seorang Konsumen terkait dengan Kendaraan Bermotor pada Roda Empat. E-JurnalAkuntansi, 24, 1632. https:// doi.org/10.24843/EJA.2018.v24.i02.p30

Alavuotunki, K., Haapanen, M., \& Pirttilä, J. (2019). The Effects of the ValueAdded Tax onRevenue andInequality. Journal ofDevelopment Studies, 55(4), 490-508. https:/ / doi.org/10.1080/00220388.2017.1400015

Alizadeh, M., \& Motallabi, M. (2016). Study the Efect of Value Aded Tax on the Size of Current Government and Construction Government. Procedia Economics and Finance, 36(16), 336-344. https://doi.org/10.1016/s22125671(16)30045-4

Ayuningtyas, D. (2010). Analisis serta Pengaruh dalam Pengenaan pada Pajak untuk Pertambahan Nilai (PPN) Dan Pajak Penjualan Atas Barang Mewah (Ppnbm) Terhadap Daya Beli Konsumen Pada Barang Elektronika (Studi Empiris Pada Konsumen Barang Elektronika Di Wilayah Tangerang Selatan). E-Journal UIN Jakarta, 11 (2).

Bikas, E. (2013). Factorss Affectting Vallue Added Tax Revennue. 24-26.

Chaerannisah. (2014). Analisis dariFaktor-Faktor yang Memengaruhi Permintaan pada sebuah Mobil yang ada di KotaMakassar. JurnalFakultas Ekonomi DanBisnis UniversitasHasanuddin.

David, P. (2012). Principlles of taxattion of road motor vehiclles and their possibillities of application. Acta Universitatis Agriculturae et Silviculturae Mendelianae Brunensis, 60(2), 483-492. https://doi.org/10.1118/acttaun 2012

Devi, S. A. P. P., \& Supadmi, N. L. (2017). Pengaruh dari pada PPN, PPnBM, serta PKB pada Tarif pajak Progresif pada Daya Beli Konsumen Kendaraan Bermotor Roda Empat. E-Jurnal Akuntansi, 18(2017), 674-704.

Eragbhe, E., \& Aronmwan, E. J. (2015). Taxpayers Income, Tax Payers Attributes And Personal Income Tax Compliance. African Journal of Management Sciences, (May), 95-111.

Fadilah. (2012). Analisis dan Pengaruh dari pada Pengenaan Pajak terhadap Pertambahan Nilai (PPN) serta Pajak Penjualan Atas Barang Mewah (PPnBM) kepada Daya Beli dari seorang Konsumen yang ada Pada Barang Elektronika (StudiEmpiris pada Konsumen BarangElektronika di Glodok Jakarta Kota). E-Journal UIN Jakarta, 1 (2).

Hetriana, T. (2015). Perilaku dari Konsumsi pada sebuah Sepeda Motor yang ada dalam sebuah Perspektif di bidang Ekonomi Islam ( pada Studi Kasus yang berada di Daerah Tanjung tepatnya Enim ). JurnalliN RadenFatah Palembang. 
Komal. (2013). An Analyssis of the Impacct of Value Aded Tax (VAT) in Delhi. GlobalJournal of Management andBusiness Studies, 3(3), 2248-9878. Retrieved fromhttp://www.ripublication.com/gjmbs.htm

Lee, S. H. (2005). An Application of a Five-Stage Consumer Behaviour Decision Making Model: An Exploratory Study of Chinese Purchasing of Imported Health Food. Journal Economic Resources.

Lulus, R., \& Surjanti, P. N. S. (2018). MotorVehicle Tax ComplianceLevels : an EmpiricalStudy and the DeterminingFactors. JournalUsm, 2(2), 21-31.

Pitaloka, L. K., Kardoyo, \& Rusdarti. (2018). TheSocialization of Tax as a ModerationVariable Towards theTaxpayer Compliance ofIndustrial Performer inKudus Regency. Journalof Economic Education, 7(1), 45-51. https:// doi.org/10.15294/jeec.v7i1.24059

Raharjo, T. P., \& Bieattant, L. (2018). Inffluence Of Taxpyer Formal Knowledge And Tax Awarenes Against Complliance Of Tax (Car Taxpayerr Case Study In Samsat Polda Bandung ). Jurnal IlmiahAkuntansi UniversitasPamulang, 6 (2), 233-241.

Rahayu, S. K. (2010). PerpajakanIndonesia: Konsepdan Aspek Formal. Yogyakarta: Grahallmu.

Ratnasari, I. A. P., \& Setiawan, P. E. (2016). PengaruhPajak Pertambahan Nilai dan PajakKendaraan Bermotor TarifProgresif Terhadap DayaBeli Kendaraandi Denpasar. E-JurnalAkuntansi, 15, 887-914.

Ridwan, M. (2012). PengaruhFaktor SosioEkonomi Kepada KepemilikanMobil dan SepedaMotor di KotaLangsa. JurnalTeknik Sipil UniversitasSyiah Kuala.

Soemitro, R. (2016). Perpajakan pada Teori serta Teknis terhadap Pemungutan. Bandung: Graha Ilmu.

Statistik, B. P. (2019). Provinsi BALI DALAMANGKA Bali Provinc In Figures 2019. Bali: BPSProvinsi Bali.

Sugiyono. (2019). Metode dalam Penelitian khusus pada Bisnis Pendekatan serta Kuantitatif, Kualitatif, Kombinasi, dan RED. Jakarta: Alfabeta.

Supawi, P. (2016). LingkunganEkonomi Bisnis. Jakarta: Cahya Gemlang.

Tareke, S., Hagos, Y., Kassa, A., \& Temesgen, G. (2013). Probllems and Prospeccts of ValueAded Tax (VAT) Implementattion in Tigrai Regionall State. Research Journali'sJournal ofAccounting, 1(1), 1-16.

Utami, K. Y. (2015). Pengaruh Pengenaan sebuah Pajak yang terdapat pada Pertambahan pada Nilai (PPN)dan PajakPenjualan Atas arang Mewah (PPnBM) Kepada Daya Beli dari seorang Konsumen AlatFotografi (StudiEmpiris pada Perhimpunan Amatir Foto di Kota Bandung). Journal Maranatha, 9 (2). 